\title{
International Trade and Investment Agreements: Sovereignty at Bay in the 21 st Century?
}

\author{
Klaus Meyer, China Europe International Business School, China \\ Daniel Rottig, Florida Gulf Coast University, USA
}

THE RULES OF THE GAME for international business (IB) are increasingly set in bilateral and multilateral treaties between nation states. Throughout the second half of the $20^{\text {th }}$ century, this regulatory framework has evolved to facilitate international business, and thus to enable economic globalization. Yet, many treaties have been controversial as citizens do not appreciate their merits relative to their associated restrictions, and governments increasingly realize the costs and risks of the related loss of sovereignty. The debate over "sovereignty at bay" led by Ray Vernon $(1968,1971)$ in the 1970s has thus been reignited. Concerned citizens resent shifts in bargaining power caused by new treaties, which are feared to limit citizens' ability to determine their own destiny, and the reduced power and influence by national governments has led to greater fiduciary risks (e.g., litigation by foreign investors against host governments through arbitration tribunals that are outside their jurisdictions).

The editors and contributors of this focused issue believe that these controversies are so important that students of IB should be aware of the key arguments, and hence teachers of IB ought to introduce these themes in their classrooms. This issue of $A I B$ Insights thus introduces pivotal contemporary controversies with the aim to stimulate classroom discussions. Moreover, we believe these issues merit more research by IB scholars, and we thus are pleased about the AIB initiative to create a new scholarly journal covering, among other topics, the supra-national institutional environment.

This introduction sets the overall stage for the debates by outlining the historical context, introducing the contributions in this special issue, and by suggesting additional resources that educators may use in their classrooms.

\section{Historical Perspective}

Traditionally, the regulatory framework for businesses has been set by the national authorities in each country. Following the principles of national sovereignty, each country established rules and regulations that applied to all persons and firms operating within its bordersincluding foreign visitors and multinational enterprises (MNEs). This national sovereignty, together with the principles of democracy, theoretically ensures that the citizens of a country can determine the rules under which they want to live.
Yet, when each country establishes its own rules, these rules are bound to be inconsistent with each other and so may create barriers to international trade and investment. Worse, the regulatory process may be captured by influential interest groups, and thus not reflect the interests of citizens at large. The classic examples are the tensions between consumers benefitting from lower prices of imported goods and domestic businesses lobbying for trade protection to curtail foreign competition and so retain their profitable businesses. National rules without coordination between nations can thus create barriers to international trade that undermine economic prosperity.

Governments around the world have committed to numerous treaties and organizations that aim to eliminate such trade barriers. Agreements have emerged both regionally and globally. For example, member countries of the European Community, as the European Union (EU) was known before 1993, committed to abolish all tariffs between member countries by the year 1968. Globally, the General Agreement on Tariffs and Trade (GATT) established a framework for the reduction of tariffs between members over the course of eight multilateral trade negotiation rounds between 1947 and 1994. While these tariff reductions clearly facilitated international trade, many other forms of trade barriers remained.

New rounds of international integration aimed to reduce non-tariff barriers. The EU, for example, introduced the principle of mutual recognition of product standards, which stipulates that all goods meeting the regulatory requirements in one member country can be freely traded within the EU. Yet, as that principle caused concerns about low standards, the EU itself assumed the responsibility for setting standards for many sectors - which by now have developed into a complex regulatory system that some believe inhibits innovation and flexibility. At a global level, the World Trade Organization (WTO), since its establishment in 1995 as a direct outcome of the final GATT trade negotiation round from 1986-1994, has introduced procedures to assess whether national rules represent trade barriers, along with an arbitrage mechanism that helps countries to solve conflicts over alleged trade barriers.

Each commitment to rules set in supra-national treaties, such as GATT (now administered under the umbrella of the WTO), or multilateral organizations, such as the WTO, create constraints on national legislators in setting rules that apply within their national boundaries. Local governments and regulators therefore cannot (normally) raise tariffs to protect an industry, subsidize domestic companies or industries to 
give them a competitive advantage over foreign competitors (and so discriminate against foreign MNEs), or introduce product standards that discriminate against imports. While the basic ideas behind such rules are relatively uncontroversial, their implementation is often complex and controversial. The long running conflicts between the EU and the US over subsidies for their aircraft industries (Airbus versus Boeing) and over health standards regarding beef (hormone treatment being illegal in the EU) illustrate the political sensitivity of these matters.

\section{New Treaties, New Commitments, New Controversies}

Recent public debates have become heated as a result of two contrarian trends. First, in the aftermath of the Great Recession of 2007-2010, governments, particularly in emerging markets, have been more protective of their economies regarding both international trade and investment leading to a new face of globalization referred to as "guarded globalization" (Bremmer, 2014), thus creating unique institutional challenges for MNEs trading with and investing in these markets (Rottig, 2016). In this focused issue, Premila Nazareth Satyanand discusses the recent revision of rights and protections of foreign investors in India according to the Indian government's new policy toward bilateral investment agreements.

Second, treaties that have recently been completed, such as the Pacific Rim's Trans-Pacific Partnership (TPP), and that are currently being negotiated, such as the US-EU Transatlantic Trade and Investment Partnership (TIPP), go much further than commitments to abolish tariffs and harmonize industry regulations that have triggered new controversies. For example, the EU-Canada Comprehensive Economic and Trade Agreement (CETA) contains commitments in at least five areas that are expected to generate economic benefits yet are opposed by some interest groups (Meyer, 2016).

First, the abolition of most tariffs is controversial in previously protected industries, such as cheese and wine producers in Canada, or beef and pork farmers in Europe. With transitory support for these particular affected industries, the principle of reducing tariffs to zero is widely supported.

Second, the commitment to align regulatory regimes may lead to some not immediately obvious complications. For example, a commitment to longer patent protection increases costs for the Canadian health care system. Also, Canadian local authorities lose the ability to favor local businesses in their procurements of goods and services. The requirement for an open tender for all public procurement has been a central element of the EU's common market regulation since the 1990s, but it is new to Canadian provinces and municipalities. In Europe, consumer groups are concerned that the treaty might open the market for food products previously banned or tightly regulated, such as hormone treated beef or genetically modified foods.

Third, the facilitation of work permits for professionals from the EU and Canada to work in each other's territories has not triggered much debate in the case of the CETA. However, this issue is more sensitive in other contexts as many national legislators have been increasing rather than reducing barriers to travel and migration in recent years.

Fourth, the CETA aims to create a level playing field for foreign direct investment in service sectors. The treaty thus commits the partners not to change their legal frameworks in ways that unfairly harm foreign investors. Concerns arise whether such commitments would disable national governments to introduce new regulations in response to emergent health, safety, or environmental concerns, as discussed in this focused issue by Christine Côté. Moreover, those favoring delivery of some services by state agencies such the National Health Service in the UK, local utilities in Germany, or social housing in the Netherlands are concerned that these services may be constrained in areas of potential competition with private foreign investors. Furthermore, the regulatory lock-in created in treaty committees appears to imply that liberalization or privatization of a sector by one government cannot be reversed if after an election a subsequent government favors a different form of regulation.

Fifth, the CETA contains a commitment to conflict resolution processes between governments and foreign investors, also known as investorstate dispute settlement (ISDS) tribunals. These controversies regarding ISDS tribunals have received the most media attention and are discussed in this focused issue by Srividya Jandhyala, by Premila Nazareth Satyanand, and by Lise Johnson and Lisa Sachs.

Public debates on the TPP and specifically the under-negotiation TTIP, which both involve the USA as a partner, raise similar issues, but have become more emotional because they also involve regulatory commitments that are expected to impact for example the use and labelling of genetically modified organisms (GMO), the regulation of financial services, geographic designations and appellations for several product categories as well as travel and visa requirements, which have become a particularly sensitive public issue due to the recent terrorist attacks in several countries.

\section{Contributions in this Focused Issue}

This focused issue contains four essays that introduce specific aspects of the broader debate on supra-national institutions, in general, and international investment agreements (IIA) and related investor-state dispute settlement (ISDS) mechanisms, in particular, and so explore "sovereignty at bay" in the $21^{\text {st }}$ century. The first essay, by Srividya Jandhyala, introduces the topic of ISDS tribunals, which she characterizes as "the most controversial aspect of global economic governance." She asks, why do countries commit to ISDS tribunals for disputes with foreign investors? Since ISDS processes are widely controversial, as they contain potential liabilities for national governments, it is necessary to consider the political processes that led to the commitment to ISDS in the first place. Jandhyala discusses three explanations for why governments may commit to ISDS and concludes that, given the wide-spread controversies about ISDS, it has become a key challenge to explore an 
improved dispute settlement mechanism based on a middle path: a balanced approach between government intervention and impartial arbitration.

Lise Johnson and Lisa Sachs take a step back and critically examine whether the purported benefits of ISDS outweigh the costs on governments. The negotiating parties of the recently completed Trans-Pacific Partnership (TPP), a trade agreement among twelve Pacific Rim countries (including the USA), suggested that the ISDS mechanism is included in the TPP in an "improved 21st century form," but Lise Johnson and Lisa Sachs argue that the changes made to the ISDS in the TPP were marginal, leaving intact most of the fundamental concerns about the traditional ISDS mechanism. These authors outline the impact of the ISDS on domestic law and institutions, on the rule of law in host government treaty parties, and on constituents and entities affected by investments and the outcome of ISDS disputes. The authors conclude that the benefits of the ISDS are tenuous at best, that the costs are significant, and that several alternative means for protecting investors' rights would be preferable to continuing to include ISDS provisions in future treaties.

Christine Côté, in her essay titled "Is It Chilly Out There? International Investment Agreements and Government Regulatory Autonomy," explores whether international investment agreements (IIAs) influence or constrain national legislators when they consider new regulation, and thus whether they may impact domestic regulatory development. Reflecting on her extensive research involving interviews and surveys of Canadian regulators in the area of health, safety, and the environment (HSE), Côté reveals that HSE regulators were unaware of the regulatory implications of IIAs and that there is little evidence that these regulators took the threat of an investment dispute into consideration when developing regulations. She then discusses the broader implications of her findings for the regulatory development in other countries. She argues that IIA-related regulatory challenges are greater in emerging economies due to their weak institutional development and concludes by raising the question of whether emerging country governments are able to make informed decisions when signing IIAs and implementing domestic regulation if governments of developed countries (such as HSE regulators in Canada) are unable to do so (or unaware when doing so).

Premila Nazareth Satyanand explicitly addresses this question in her essay titled "Once BITten, Forever Shy: Explaining India's Rethink of Its Bilateral Investment Treaty Provisions." In the specific emerging market context of India, she illustrates how the local government deliberately changed its policy toward bilateral investment agreements (BITs) as a direct result of the considerable liabilities it faced due to several disputes involving litigation by foreign investors. She illustrates these liabilities based on several brief cases of foreign investors that have litigated against the Indian government under the auspices of ISDS provisions included in IIAs signed by the government, and then discusses the key ideological changes of the Indian government toward BITs and the implications for foreign investors.

\section{Further Resources for Educators}

Multilateral institutions are commonly introduced in the classroom by focusing on international trade and thus the WTO. A discussion of the WTO and its arbitrage mechanisms lays a good foundation for discussing ISDS-related issues. Popular cases to discuss the WTO arbitrage mechanism include the Bombardier Embraer conflict (either Harvard \#9-703-022 or Ivey \# 9A99M004). Also, a two-volume set of case studies in multilateral trade policymaking and dispute settlement is available via the Peterson Institute for International Economics. Volume 1 (ISBN 0-88132-362-4) includes a total of five cases on trade negotiations and trade policy rulemaking, and Volume 2 (ISBN 0-88132-363-2) presents six additional cases on key trade disputes at the WTO and dispute resolution in the trading system. The set also includes a case study on the failure of the multilateral agreement of investment (MAI). Combined, these cases help IB educators to illustrate how trade policy actually works and so bring the reality of trade policy into the classroom. At this time, we are not aware of good cases on international investment agreements, or specifically on ISDS, such that we recommend using policy documents as a foundation for classroom discussion.

Instructors wishing to provide further materials to their students will find the websites of the United Nations Conference on Trade and Development (UNCTAD) a valuable resource. First, the investment policy hub website (http://investmentpolicyhub.unctad.org/) provides a variety of different sources ranging from statistical data, recent analytical reports, reform proposals, and blogs on investment policy related topics. For example, an interesting study published in June 2015 reviews all cases brought to ISDS by Dutch companies, the majority of which in fact are subsidiaries of MNEs headquartered in third countries. ${ }^{1}$ Second, the World Investment Report (WIR), published annually by UNCTAD, provides not only rich data and an analysis of FDI flows and stocks but also overviews of contemporary policy issues related to FDI and MNEs. ${ }^{2}$ For example, the 2015 WIR (UNCTAD, 2015) contains a detailed review of the debates around international investment treaties (see chapter IV of the report).

Alternatively, educators may consult the following two websites, which provide information on dispute resolution primarily from a legal perspective: www.transnational-dispute-management.com and www. naftaclaims.com. Some legal cases have gained considerable attention in the media and can be introduced on the basis of newspaper reports, most notably the use of international arbitration mechanisms by the tobacco industry in its fight against labelling requirements and other restrictions (see, e.g., www.mccabecentre.org/focus-areas/tobacco/ philip-morris-asia-challenge).

In conclusion, new regulations created through international treaties and multilateral organizations have potentially profound implications for international direct investments, and hence the operations of multinational enterprises. We hope the essays in this focused issue will encourage our colleagues to introduce these topics in their classrooms. 


\section{References}

Bremmer, I. 2014. The new rules of globalization. Harvard Business Review, 92(1): 103-107.

Meyer, K. E. 2016. Canada and the EU negotiate CETA. In M.W. Peng \& K.E. Meyer, International Business (2 ${ }^{\text {nd }}$ edn). London: Cengage Learning.

Rottig, D. 2016. Institutions and emerging markets: Effects and implications for multinational corporations. International Journal of Emerging Markets, 11(1): 2-17.

UNCTAD. 2015. World Investment Report 2015. Geneva: UNCTAD.

Vernon, R. 1968. Economic sovereignty at bay. Foreign Affairs, 47(1): 110-122.

Vernon, R. 1971. Sovereignty at bay: The multinational spread of US enterprises. New York: Longman.

\section{Endnotes}

1 http://investmentpolicyhub.unctad.org/Upload/Documents/treatybased-isds-cases-brought-under-dutch-iias-an-overview.pdf

2 http://unctad.org/en/Pages/DIAE/World\%20Investment\%20Report/ World_Investment_Report.aspx
Klaus Meyer (kmeyer@ceibs.edu) is the Philips Chair and Professor of Strategy and International Business at China Europe International Business School (CEIBS) where he moved from the UK in 2011. He is a Fellow and a former Vice President of the AIB. In 2015, he received the JIBS Decade Award. He published over 60 articles in scholarly journals, mostly in Journal of International Business Studies, Strategic Management Journal and Journal of Management Studies.

Daniel Rottig (drottig@fgcu.edu) is Associate Professor of International Business and Strategic Management in the Lutgert College of Business at Florida Gulf Coast University. He is a Fellow and former Chairman of the AIB Southeast USA Chapter. He has published in Management International Review, Thunderbird International Business Review, Academy of Management Learning and Education, Decision Sciences Journal and other respected outlets and received several awards and award-nominations from the AIB and the Academy of Management. 